\title{
Peran Unit Pengembangan Karir dan Kewirausahaan di Perguruan Tinggi (Studi Tentang Proses Rekrutmen Tenaga Kerja Melalui UPKK Universitas Brawijaya)
}

\author{
Farah Dillah ${ }^{a^{*}}$ \\ ${ }^{a}$ Universitas Brawijaya, Malang, Jawa Timur, Indonesia
}

\section{INFORMASI ARTIKEL}

\section{Article history:}

Dikirim tanggal: 01 Februari 2016

Revisi pertama tanggal: 17 Februari 2016

Diterima tanggal: 01 November 2016

Tersedia online tanggal: 16 November 2016

Keywords: student, job, company

\section{ABSTRACT}

The findings in the field shows that Unit Career Development and Entrepreneurship of UB (UPKK UB) held a recruitment process in two ways namely through campus hiring or hold a job fair. Companies that recruit prospective employees in the internal environment (campus hiring) Universitas Brawijaya is helped because to get human resources in accordance with the criteria of the company. In addition to campus hiring flagship programs and Entrepreneurship Career Development Unit of UB itself is organizing a job fair or commonly called the job market which is a container or where the labor force to seek and obtain information about job opportunities open and objective. Factors supporting the recruitment Unit Career Development and Entrepreneurship of UB consists of Bargaining Universitas Brawijaya, quality of alumni were nice, and a broad network while limiting factors are the weakness of the system information technology and the lack of making MoU (Memorandum of Understanding) among some faculty with industry within the internal scope of UB.

\section{INTISARI}

Unit Pengembangan Karir dan Kewirausahaan Universitas Brawijaya (UPKK UB) menyelenggarakan proses rekrutmen melalui dua cara, yakni lewat campus hiring atau mengadakan job fair. Perusahaan yang melakukan rekrutmen calon pegawai diinternal lingkungan (campus hiring) UB sangatlah terbantu karena mendapatkan sumber daya manusia yang sesuai dengan kriteria perusahaan. Selain campus hiring program andalan UPKK UB adalah menyelenggarakan job fair atau biasa disebut dengan bursa kerja yang mana merupakan wadah atau tempat para tenaga kerja untuk mencari dan mendapatkan informasi tentang kesempatan kerja yang terbuka dan obyektif. Faktor pendukung rekrutmen di UPKK UB terdiri dari bargaining Universitas Brawijaya, kualitas alumni yang bagus, dan jaringan yang luas sedangkan faktor penghambatnya yakni lemahnya sistem teknologi informasi dan minimnya pembuatan nota kesepemahaman antara beberapa fakultas dengan dunia industri dalam lingkup internal Universitas Brawijaya.

2016 FIA UB. All rights reserved.

\section{Pendahuluan}

Tingginya jumlah mahasiswa yang menuntut ilmu di Universitas Brawijaya saat ini tidak berbanding lurus dengan jumlah lapangan kerja yang tersedia, oleh karena itu Universitas Brawijaya mendirikan Unit Pengembangan Karir dan Kewirausahaan untuk memfasilitasi para alumni untuk mendapat pekerjaan

\footnotetext{
* Corresponding author. Tel.: +62-857-9171-3983; e-mail: fdillah83@ gmail.com
} 
yang lebih baik dan lengkap, hal ini sesuai pada Bab IV Undang-Undang No. 13 Tahun 2003 tentang Ketenagakerjaan pada pasal 39 dan pasal 40, yaitu tentang Perluasan Kesempatan Kerja bagi tenaga kerja yang sedang mencari pekerjaan, dimana institusi pendidikan, masyarakat, dan pemerintah bersama-sama mengupayakan perluasan kesempatan kerja baik didalam maupun diluar negeri.

Selain itu sebagai salah satu universitas terkemuka yang telah menghasilkan banyak prestasi maka Universitas Brawijaya dituntut untuk dapat menghasilkan pula alumni atau calon tenaga kerja yang profesional dan memenuhi standar dunia kerja bertaraf nasional maupun internasional. Apalagi dengan diterapkannya kebijakan Masyarakat Ekonomi ASEAN membuat persaingan dalam dunia kerja menjadi semakin tinggi. Lulusan Universitas Brawijaya menurut data Unit Pengembangan Karir dan Kewirausahaan ratarata menganggur dalam rentang waktu enam bulan sejak kelulusan mereka.

Bagi alumni secara keseluruhan, Unit Pengembangan Karir dan Kewirausahaan Universitas Brawijaya selalu menggelar pelatihan dan pengembangan karir tiap dua bulan sekali untuk memberikan informasi kepada lulusan Universitas Brawijaya mengenai dunia kerja. Hal inilah, yang menjadikan lulusan Universitas Brawijaya tidak sampai bertahun-tahun menganggur lama untuk menunggu kerja, semua pelatihan ini juga bersifat gratis untuk lulusan Universitas Brawijaya sehingga sangat membantu dan bermanfaat karena dalam dunia industri pintar saja kurang diminati, apalagi pintar hanya dalam hal akademik saja tidaklah cukup.

Selain itu ada tiga hal mendasar yang dicari perusahaan dari para pencari kerja, yaitu kreatif, inisiatif, dan memiliki kepekaan sosial. Karena jika hanya bermodal Indeks Penilaian Kumulatif sudah banyak. Tapi yang memiliki tiga hal ini yang sulit. Dan di pelatihan-pelatihan Unit Pengembangan Karir dan Kewirausahaan, ketiga hal itu diupayakan untuk dimiliki lulusan Universitas Brawijaya.

Sejarah Unit Pengembangan Karir dan Kewirausahaan sendiri bermula dari keinginan Universitas Brawijaya membentuk suatu unit khusus yang secara profesional menangani perihal Karir dan Dunia Kerja, unit tersebut pada awalnya bernama $J o b$ Placement Center (JPC) yang didirikan pada tahun 1995. Pada Tahun 2013, berdasar SK Rektor Nomor: 199/SK/2013 Tanggal 24 April 2013; nama JPC diubah menjadi JPC dan Tracer Study karena ada pengembangan bidang Tracer Study yang dimasukkan kedalam unit tersebut dan pada akhirnya mulai Tahun 2015 berubah nama menjadi Unit Pengembangan Karir dan Kewirausahaan berdasarkan Surat Keputusan Rektor Nomor 188 Tahun 2015 tertanggal 29 April 2015 tentang Struktur Organisasi Unit Pengembangan Karir dan Kewirausahaan (UPKK) untuk menggantikan struktur Job Placement Center dan Tracer Study. Unit Pengembangan Karir dan Kewirausahaan pada awalnya merupakan unit di Universitas Brawijaya yang bertujuan menjadi pusat informasi dan pelatihan serta pengembangan diri bagi mahasiswa dan alumni dalam memasuki dunia kerja, menjadi penghubung antara Perguruan Tinggi dengan institusi pemerintah, dunia usaha dan dunia industri, mempersiapkan mahasiswa dan alumni memiliki wawasan wirausaha, menjadi pusat data dan informasi tracer study Universitas Brawijaya.

Sebagai unit yang diberikan kepercayaan penuh dalam hal karir dan dunia kerja maka Unit Pengembangan Karir dan Kewirausahaan Universitas Brawijaya berkewajiban untuk selalu menyampaikan informasi, pelatihan, maupun fasilitas kepada para alumni sehingga alumni Universitas Brawijaya memiliki kemampuan dan rasa percaya diri untuk bersaing di dalam dunia kerja bertaraf Nasional maupun Internasional. Selain itu tujuan lain Unit Pengembangan Karir dan Kewirausahaan Universitas Brawijaya ialah sebagai pusat informasi lowongan kerja dan pelatihan serta pengembangan dalam mempersiapkan mahasiswa dan alumni guna mampu bersaing di dalam dunia kerja pada era globalisasi, serta menjadi perantara antara Perguruan Tinggi dengan Dunia Usaha dan Industri dalam skala Nasional maupun Internasional.

Melalui Unit Pengembangan Karir dan Kewirausahaan Universitas Brawijaya, perusahaan juga dapat melakukan perekrutan pegawai di internal lingkungan Universitas Brawijaya dan adanya proses rekrutmen ini sangat membantu perusahaan untuk mendapatkan sumber daya manusia yang sesuai dengan harapan perusahaan, karena dengan mengunakan sistem rekrutmen tersendiri dapat menciptakan sumber daya manusia atau memilah sendiri calon pekerja yang berkualitas.

Salah satu program andalan Unit Pengembangan Karir dan Kewirausahaan Universitas Brawijaya sendiri adalah kegiatan job fair atau biasa disebut dengan bursa kerja yang mana merupakan wadah atau tempat para tenaga kerja untuk mencari dan mendapatkan informasi tentang kesempatan kerja yang terbuka dan obyektif. Tujuan Job Fair tentu saja untuk menyerap tenaga kerja dan mengurangi tingkat pengangguran. Manfaat untuk perusahaan antara lain mereka dapat menemukan banyak kandidat atau calon karyawan untuk perusahaan mereka. Sedangkan manfaat dari Job Fair untuk para pencari kerja merupakan tempat menemukan berbagai pekerjaan yang cukup potensial. Dimana mereka bisa memasukan lamaran langsung ke bagian rekrutmen dari masing-masing perusahaan. Informasi posisi pekerjaan yang dibutuhkan pun lebih akurat dan juga terdapat banyak pilihan jenis posisi pekerjaan. Tujuan dalam 
penelitian ini ialah untuk mendeskripsikan atau mengetahui bagaimanakah proses rekrutmen tenaga kerja melalui Unit Pengembangan Karir dan Kewirausahaan Universitas Brawijaya Malang serta mengetahui faktor-faktor pendukung dan penghambatnya.

\section{Teori}

\subsection{Manajemen Sumber Daya Manusia}

Manajemen sumber daya manusia adalah penarikan, seleksi, pengembangan, pemeliharaan, dan penggunaan sumber daya manusia untuk mencapai titik tujuan-tujuan individu maupun organisasi (Handoko, 2000:4). Manajemen sumber daya manusia merupakan suatu perencanaan, pengorganisasian, pengkoordinasian, pelaksanaan dan pengawasan terhadap pengadaan, pengembangan, pemberian balas jasa, pengintegrasian, pemeliharaan dan pemisahan tenaga kerja dalam rangka mencapai tujuan organisasi (Mangkunegara, 2002:2). Manajemen sumber daya manusia adalah ilmu dan seni mengatur hubungan dan peranan tenaga kerja agar efektif dan efisien membantu terwujudnya tujuan perusahaan, karyawan dan masyarakat (Hasibuan, 2002:10). Manajemen sumber daya manusia merupakan salah satu bidang dari manajemen umum yang meliputi segi-segi perencanaan, pengorganisasian, pelaksana dan pengendalian (Rivai, 2005:1).

\subsection{Rekrutmen Tenaga Kerja}

Rekrutmen merupakan salah satu kegiatan yang sangat penting dalam manajemen sumber daya manusia, sebab merupakan awal dari kegiatan dalam rangka mendapatkan pegawai yang tepat untuk mengisi jabatan tersebut. Menurut Hariandja (2007:96) rekrutmen diartikan sebagai proses penarikan sejumlah calon yang berpotensi untuk diseleksi menjadi pegawai. Sedangkan Sastrohadiwiryo (2005:138) mengatakan pengertian Rekruitmen adalah suatu proses mencari tenaga kerja dan mendorong serta memberi harapan kepada mereka untuk melamar pekerjaan pada perusahaan.

\subsection{Kompetensi}

Kompetensi merupakan landasan dasar karakteristik orang dan mengindikasikan cara berperilaku atau berpikir, menyamakan situasi, dan mendukung untuk periode waktu yang lama (Spencer dan Spencer, 1993:9). Secara garis besar, kompetensi menjelaskan apa yang dilakukan orang di tempat kerja pada berbagai tingkatan dan memperinci standar masing-masing tingkatan, mengidentifikasi karakteristik pengetahuan, dan ketrampilan yang diperlukan individual yang memungkinkan menjalankan tugas dan tanggung jawab secara efektif sehinggga mencapai standar kualitas profesional dalam bekerja.

\subsection{Pasar Tenaga Kerja}

Menurut Simanjuntak (2001:101), pasar kerja adalah seluruh aktivitas dari pelaku-pelaku yang mempertemukan pencari kerja dan lowongan kerja. Pelaku ini terdiri dari pengusaha tenaga atau perusahaan, pencari kerja (job seeker), perantara atau pihak ketiga yang memberikan kemudahan bagi pengusaha dan pencari kerja untuk saling berhubungan. Pasar tenaga kerja dapat diartikan sebagai suatu pasar yang mempertemukan penjual dan pembeli tenaga kerja. Sebagai penjual tenaga kerja dalam pasar ini adalah para pencari kerja (pemilik tenaga kerja), sedangkan sebagai pembelinya adalah orang-orang atau lembaga yang memerlukan tenaga kerja. Pasar tenaga kerja diselenggarakan dengan maksud untuk mengkoordinasi pertemuan antara para pencari kerja dan orang-orang atau lembaga-lembaga yang membutuhkan tenaga kerja.

\section{Metode Penelitian}

Penelitian yang digunakan oleh penulis dalam penyusunan skripsi ini adalah penelitian deskriptif dengan pendekatan kualitatif. Penelitian dengan pendekatan kualitatif menurut Bogdan dan Taylor yang dikutip oleh Moleong (2006:4) merupakan prosedur penelitian yang menghasilkan data deskriptif berupa kata-kata tertulis atau lisan dari orang-orang dan perilaku yang dapat diamati. Dengan demikian data kualitatif adalah data yang berupa kata dan atau kalimat, gambar, skema, yang belum diangkakan. Adapun yang menjadi fokus penelitian, adalah sebagai berikut:

1) Proses Perekrutan Tenaga kerja melalui Unit Pengembangan Karir dan Kewirausahaan Universitas Brawijaya Malang yakni melalui Campus Hiring

2) Faktor pendukung dan penghambat proses Rekrutmen Tenaga kerja melalui Unit Pengembangan Karir dan Kewirausahaan Universitas Brawijaya Malang

a) Faktor Pendukung:

- Kualitas akademik yang bagus; dan

- Jaringan yang luas.

b) Faktor Penghambat:

- Lemahnya sistem teknologi informasi; dan

- Banyak fakultas yang belum memiliki kerjasama dengan bidang industri.

Lokasi penelitian adalah ruang atau tempat dimana peneliti akan mengungkapkan keadaan yang sebenarnya dari obyek yang akan diteliti. Dalam penelitian ini, peneliti mengambil lokasi di kantor Unit Pengembangan Karir dan Kewirausahaan (UPKK) Universitas Brawijaya Malang. Alasan penelitian dilakukan di lokasi tersebut adalah karena UPKK merupakan unit organisasi untuk melihat keberhasilan lulusan dalam memasuki dunia kerja. Sedangkan situs penelitian merupakan tempat dimana sebenarnya peneliti melakukan penelitian guna memperoleh data maupun informasi yang 
berkaitan dengan masalah yang akan diteliti. Adapun situs dalam penelitian ini, antara lain sebagai berikut:

1) Ruang Kepala UPKK Universitas Brawijaya;

2) Ruang interview UPKK Universitas Brawijaya; dan

3) Ruang pelatihan UPKK Universitas Brawijaya.

Jenis data yang diperlukan dalam penelitian ini adalah jenis data primer yaitu meliputi, Manajer HRD dari Bank BRI, manajer HRD PT REA Kalimantan Timur, Ketua UPKK Universitas Brawijaya, dan Kepala Bidang Pengembangan Karir UPKK Universitas Brawijaya. Kemudian yang kedua, yaitu jenis data sekunder yang meliputi buku profil Kantor UPKK Universitas Brawijaya.

Teknik pengumpulan data yang dipergunakan dalam penelitian ini yaitu; interview (wawancara), observasi, dan dokumentasi. Instrumen penelitian meliputi peneliti sendiri, pedoman wawancara, dan perangkat penunjang. Analisis data yang digunakan penelitian, yaitu menggunakan model interaktif dari Miles dan Hubberman (2007:16-19). Sedangkan analisis data terdiri dari alur kegiatan yang meliputi: pengumpulan data, reduksi data, penyajian data, dan menarik kesimpulan/ verifikasi.

\section{Hasil Penelitian dan Pembahasan}

Proses Rekrutmen Tenaga kerja melalui Unit Pengembangan Karir dan Kewirausahaan (UPKK) Universitas Brawijaya Malang ialah melalui campus hiring. Campus hiring sendiri adalah sebuah proses penerimaan secara mandiri dari sebuah perusahaan yang utamanya memiliki kerjasama dengan Universitas Brawijaya untuk melakukan rekrutmen di internal kampus dengan peserta mayoritas adalah mahasiswa Universitas Brawijaya. Selain itu dunia kerja yang semakin ketat dan kebutuhan akan sumber daya manusia semakin meningkat membuat banyak alumni, calon wisudawan, maupun mahasiswa berkompetisi untuk mendapatkan pekerjaan membuat perusahaan juga harus lebih turun ke lapangan supaya mendapat calon karyawan yang berkualitas. Atas pertimbangan ini juga maka Unit Pengembangan Karir dan Kewirausahaan Universitas Brawijaya mengadakan Campus Hiring. Melalui Campus Hiring ini alumni maupun mahasiswa Universitas Brawijaya dapat mempersiapkan diri mereka untuk masuk dalam dunia profesional bahkan memulai karir yang panjang dari sini. Campus Hiring ini merupakan inovasi dari proses rekrutmen yang diadakan oleh perusahaan yang bekerjasama dengan Unit Pengembangan Karir dan Kewirausahaan Universitas Brawijaya dan dikemas dengan rancangan yang lebih sederhana. Tujuan lain dari Campus Hiring adalah untuk mempercepat proses perekrutan kerja bagi mahasiswa terutama alumni dalam membangun karir dan masuk dalam dunia profesional karena apabila mendaftar di internal perusahaan atau melalui lembaga outsource memakan waktu lama dan berbelit. Selain itu Unit Pengembangan Karir dan Kewirausahaan Universitas Brawijaya memiliki corporate partner yang bonafide dalam jumlah yang banyak sehingga peluang kerja yang tersedia juga lebih banyak, untuk faktor pendukung rekrutmen dalam kampus yang pertama ialah kualitas akademik yang bagus yang dibuktikan dengan banyaknya prestasi akademik, sehingga menjadi pendorong bagi perusahaan untuk melakukan open recruitment disini. Selain itu di sini juga seringkali diadakan evaluasi berkala dari petinggi kampus untuk membenahi kurikulum bahkan merombak untuk memperbaiki kualitas alumni Universitas Brawijaya, sehingga bisa selaras dengan dunia industri. Kemudian faktor yang kedua ialah jaringan yang luas karena sebagai universitas yang didirikan sejak Tahun 1963 tidaklah salah apabila Univesitas Brawijaya memiliki jaringan yang luas. Karena sudah sangat banyak jaringan dari Univesitas Brawijaya yang telah menduduki banyak posisi penting baik pemerintahan maupun swasta.

Sedangkan faktor penghambatnya ialah lemahnya sistem teknologi informasi yang ada baik dalam penyampaian informasi lowongan kepada para alumni Universitas Brawijaya maupun kepada perusahaan. Padahal dalam era teknologi seperti ini tuntutan untuk memaksimalkannya merupakan sebuah keharusan untuk tetap update informasi, padahal situs pencari kerja profesional mampu secara real time menampilkan update informasi bahkan memberikan informasi lowongan secara gratis melalui e-mail bagi membernya. Selain itu banyak fakultas yang belum memiliki kerjasama dengan bidang industri.

\section{Kesimpulan}

Proses rekrutmen tenaga kerja melalui Unit Pengembangan Karir dan Kewirausahaan (UPKK) Universitas Brawijaya Malang berupa campus hiring sudah berjalan dengan cukup baik selama ini namun dalam dunia kerja selain lulusan dari universitas dan fakultas yang sesuai keinginan penyedia lapangan kerja ada tiga hal mendasar yang dicari perusahaan dari para pencari kerja, yaitu kreatif, inisiatif, dan memiliki kepekaan sosial. Namun sampai saat ini pemolesan para alumnus untuk mengasah tiga hal ini belum maksimal. Faktor pendukung yang terdiri dari kualitas alumni yang bagus dan jaringan yang luas hendaknya bisa dimaksimalkan mungkin bagi Unit Pengembangan Karir dan Kewirausahaan Universitas Brawijaya Malang utamanya untuk membangun kerjasama dengan perusahaan bonafide yang memilki reputasi multinasional untuk memfasilitasi para alumnus Universitas Brawijaya untuk mendapatkan pekerjaan serta jenjang karir yang bagus ke depannya. Adapun faktor penghambat dalam rekrutmen tenaga kerja 
melalui Unit Pengembangan Karir dan Kewirausahaan Universitas Brawijaya Malang terdiri dari dua hal, yakni lemahnya sistem teknologi informasi dan minimnya pembuatan kesepemahaman antara beberapa fakultas dengan dunia industri dalam lingkup internal Universitas Brawijaya bisa diselesaikan dengan pembenahan pada dua sektor tersebut.

\section{Daftar Pustaka}

Mangkunegara, Anwar Prabu. (2002). Manajemen Sumber Daya Manusia. PT. Remaja Rosda Karya, Bandung.

Hani, Handoko T. (2000). Manajemen Personalia dan Sumberdaya Manusia, Edisi II, Cetakan Keempat Belas. Penerbit BPFE, Yogyakarta.

Hariandja, Marihot Tua Efendi. (2007). Manajemen Sumber Daya Manusia: Pengadaan, Pengembangan, Pengkompensasian, dan Peningkatan Produktivitas Pegawai. Grasindo, Jakarta.

Hasibuan, Malayu S.P. (2002). Manajemen Sumber Daya Manusia. Bumi Aksara, Jakarta.

Miles, Mathew B., \& Hubberman, Michael A. (2007). Analisis Data Kualitatif. Universitas Indonesia, Jakarta.

Moleong, Lexy J. (2006). Metodologi Penelitian Kualitatif. PT. Remaja Rosdakarya, Bandung.

Rivai, V. (2005). Manajemen Sumber Daya Manusia Untuk Perusahaan Dari Teori Ke Praktek. PT. Raja Grafindo Persada, Jakarta.

Sastrohadiwiryo, B.S. (2005). Manajemen Tenaga Kerja Indonesia Pendekatna Administratif Dan Personal. Jakarta: PT Bumi Aksara.

Simanjuntak, Payaman. (2001). Pengantar Ekonomi Sumber Daya Manusia. Jakarta: LPFE UI.

Spencer, Lyle, M.Jr., \& Spencer, Signe M. (1993). Competence at Work. New York: John Wiley \& Sons, Inc.

Surat Keputusan Rektor Nomor 188 Tahun 2015 Tanggal 29 April 2015 tentang Struktur Organisasi Unit Pengembangan Karir dan Kewirausahaan.

Undang - Undang Nomor 13 Tahun 2003 tentang Ketenagakerjaan. 